\title{
Resting energy expenditure adaptation after short-term caloric restriction in morbidly obese women
}

\author{
Adaptação do gasto energético de repouso após \\ restrição calórica de curto prazo em \\ mulheres com obesidade mórbida
}

\author{
Andresa Toledo TRIFFONI-MELO' \\ Vivian Marques Miguel SUEN ${ }^{1}$ \\ Cristina Maria Mendes RESENDE² \\ Camila Bitu Moreno BRAGA ${ }^{1}$ \\ Rosa Wanda DIEZ-GARCIA ${ }^{1}$
}

\section{Objective}

The objective of this study was to describe changes in the resting energy expenditure, substrate oxidation rate, and body composition in morbidly obese women subjected to short-term caloric restriction.

\section{Methods}

This was a prospective study that included ten obese women with body mass index greater than $40 \mathrm{~kg} / \mathrm{m}^{2}$ and aged between 20-50 years. The participants were hospitalized for eight days and received a controlled conventional low-calorie diet, $1200 \mathrm{kcal} /$ day, for seven days. Body weight, body mass index, abdominal circumference, body composition, resting energy expenditure, and substrate oxidation rate were evaluated at the beginning and at the end of the study.

\section{Results}

A significant reduction in body weight $(p=0.005)$, body mass index $(p=0.005)$, abdominal circumference $(p=0.005)$, fat mass $(p=0.005)$ and fat-free mass $(p=0.008)$ was observed at the end of the study. There was an average reduction in resting energy expenditure of approximately $124 \mathrm{kcal} /$ day $(5 \%)$. Substrate oxidation rate did not show statistically significant changes. There was a positive correlation only between body weight reduction and fat-free mass reduction ( $r=0.753 ; p=0.012)$.

\footnotetext{
1 Universidade de São Paulo, Faculdade de Medicina, Departamento de Medicina Interna. Av. Bandeirantes, 3900, Monte Alegre, 14049-900, Ribeirão Preto, SP, Brasil. Correspondência para/Correspondence to: RW DIEZ-GARCIA. E-mail: <wanda@fmrp.usp.br>.

2 Universidade de São Paulo, Faculdade de Medicina, Departamento de Puericultura e Pediatria. Ribeirão Preto, SP, Brasil.
} 


\section{Conclusion}

There was an adaptive response of the resting energy expenditure with short-term energy restriction in morbidly obese women with a $5 \%$ reduction in resting energy expenditure and a positive correlation between weight loss and the fat-free mass, which indicates the influence of fat-free mass on the decrease in resting energy expenditure. Therefore, short-term caloric restriction in morbidly obese women led to a decrease in resting energy expenditure and fat-free mass, which suggests a rapid adaptation of energy expenditure.

Keywords: Adaptation, physiological. Caloric restriction. Energy metabolism. Obesity. Weight loss.

\section{R E S U M O}

\section{Objetivo}

Descrever as mudanças no gasto energético de repouso, na taxa de oxidação de substrato e na composição corporal em mulheres obesas mórbidas submetidas à restrição calórica de curto prazo.

\section{Métodos}

Este foi um estudo prospectivo com dez mulheres obesas com índice de massa corporal maior que $40 \mathrm{~kg} / \mathrm{m}^{2} \mathrm{e}$ idade entre 20-50 anos. As participantes foram hospitalizadas por sete dias consecutivos e receberam uma dieta hipocalórica convencional controlada de $1200 \mathrm{kcal/dia}$. Peso corporal, índice de massa corporal, circunferência abdominal, composição corporal, gasto energético de repouso e taxa de oxidação de substratos foram avaliados no início e no final do estudo.

\section{Resultados}

Reduções significativas no peso corporal $(p=0,005)$, indice de massa corporal $(p=0,005)$, circunferência abdominal $(p=0,005)$, massa gorda $(p=0,005)$ e massa livre de gordura $(p=0,008)$ foram observadas no final do estudo. $O$ gasto energético de repouso mostrou redução média de aproximadamente $124 \mathrm{kcal} / \mathrm{dia}$ (5\%). A taxa de oxidação de substratos não apresentou mudanças estatisticamente significativas. Houve correlação importante apenas entre a redução do peso corporal e a redução da massa livre de gordura $(r=0,753, p=0,012)$.

\section{Conclusão}

Houve uma resposta adaptativa do gasto energético de repouso com restrição energética em curto prazo em mulheres obesas mórbidas, apresentando redução média de 5\% do gasto energético de repouso e correlação entre a perda de peso e a massa livre de gordura, o que indica a influência da mesma na diminuição do gasto energético de repouso. Portanto, a restrição calórica de curto prazo em mulheres obesas mórbidas leva à diminuição no gasto energético de repouso e na massa livre de gordura, sugerindo uma rápida adaptação do gasto energético.

Palavras-chave: Adaptação fisiológica. Restrição calórica. Metabolismo energético. Obesidade. Perda de peso.

\section{INTRODUCTION}

Physiological adaptation has been well established in obese people, particularly in obese adults with a Body Mass Index (BMI) between 30 and $39 \mathrm{~kg} / \mathrm{m}^{2}$, and Resting Energy Expenditure (REE) reduction has been observed in situations of energy restriction ${ }^{1-7}$. However, there are few studies on short-term energy restriction in morbidly obese people to verify the adaptive response ${ }^{8,9}$. Obesity is difficult to treat and it is associated with many comorbidities. Weight gain, in turn, is associated with metabolic changes that favor insulin resistance and dyslipidemia, among other conditions ${ }^{10}$.

Weight loss in obese subjects has been impaired by REE reduction, with the occurrence of weight regain, leading to treatment failure ${ }^{11}$. Hypocaloric diets with different macronutrient composition similarly decrease REE in obese women. However, reduction in waist circumference and body composition is greater when carbohydrate is replaced in the diet with protein ${ }^{12}$. In addition to the REE reduction, weight loss has also been associated with reduced insulin resistance, leading to changes in the pattern of 
energy substrate utilization, i.e., a reduced rate of lipid utilization and increased rate of glucose utilization as an energy source ${ }^{11}$.

In view of these considerations, the present study aimed to describe the effects of short-term caloric restriction on the REE, substrate oxidation rate, and body composition in morbidly obese women to learn about the adaptive process in these subjects.

\section{METHOD S}

This prospective study evaluated 10 morbidly obese women (BMI higher than $40 \mathrm{~kg} / \mathrm{m}^{2}$ ) aged 20 to 50 years without worsening their health conditions. The participants who had diabetes Mellitus, were taking diuretics and metformin, or had chronic renal and hepatic insufficiency, endocrine diseases as the cause of obesity, disorders of eating behavior, serious psychiatric diseases (including the use of alcohol or drugs), neoplasias, or active systemic inflammatory or infectious diseases were excluded from the study.

The participants were recruited from a list of patients that were being treated at the Bariatric Surgery Clinic of the University Hospital, Ribeirão Preto Medical School, Universidade de São Paulo (USP). The selected participants were hospitalized and monitored by a multiprofessional team for eight days at this hospital and were offered a standard low-calorie diet of 5020.8 kJ/day (1200 $\mathrm{kcal} /$ day) for seven days. The diet consisted of 171 g carbohydrate (54\%), 74 g protein ( $23 \%$ ), and $32 \mathrm{~g}$ lipid (23\%) fractionated into six meals a day. All participants were instructed to consume all the food offered.

The participants were evaluated on days one and eight of the study at 7:00 a.m. after a 12 hour overnight fast. To determine REE (formula 1), in $\mathrm{kcal} /$ day, the values of oxygen consumption $\left(\mathrm{VO}_{2}\right)$ and carbon dioxide production $\left(\mathrm{VCO}_{2}\right)$, measured by indirect calorimetry using a mobile Vmax 29 Sensor Medics ${ }^{\circledR}$ calorimeter (Sensor Medics Corporation, Yorba Linda, California, United States), were applied to Weir ${ }^{13}$ equation:
$\mathrm{REE}=3.94 \times \mathrm{Vo}_{2}+1.106 \times \mathrm{VCO}_{2} \times 1440$

With regard to the substrate oxidation rate, glucose and lipid oxidation (equations 2 and 3 ) were calculated using the $\mathrm{VO}_{2}, \mathrm{VCO}_{2}$, and excreted urinary nitrogen $(\mathrm{Nu})$ values in the Frayn ${ }^{14}$ equations:

$$
\begin{aligned}
& \text { Glucose }(\mathrm{g})=4.55 \mathrm{VCO}_{2}-3.21 \mathrm{Vo}_{2}-2.87 \mathrm{~N} \\
& \text { Lipid }(\mathrm{g})=1.67 \mathrm{VO}_{2}-1.67 \mathrm{VCO}_{2}-1.92 \mathrm{~N}
\end{aligned}
$$

The respiratory quotient was calculated as the $\mathrm{VCO}_{2} \mathrm{NO}_{2}$ ratio. The protein oxidation (equation 4) was calculated using Schutz's ${ }^{15}$ method:

Protein $(\mathrm{g})=6.25 \mathrm{~N}$

The measurements of height, body weight and $\mathrm{BMI}^{16}$, abdominal circumference ${ }^{17}$, and also bioelectrical impedance, used to determine fatfree mass and fat mass, were performed according to standardized techniques. Since the patients in this study exceeded maximum weight limit (120 kg), the bioelectrical impedance method was used instead of the gold standard method (DXA, Dual Energy X-Ray Absorptiometry). Bioelectrical impedance was performed using a Biodynamics BIA 450 apparatus in order to obtain fat-free mass and fat mass values ${ }^{18}$. Height was measured using a $2.0 \mathrm{~m}$ long graduated metal rod (precision of $0.5 \mathrm{~cm}$ ). Body weight was measured using a Filizola ${ }^{\circledR}$ electronic scale, precision of $200 \mathrm{~g}$, and $300 \mathrm{~kg}$ capacity. The subjects were weighed standing up erect, barefoot, and wearing minimal clothing. BMI was determined as the ratio of weight to height squared. Abdominal circumference was measured using an inextensible measuring tape at the level of the umbilical scar due to the changes in body shape due to severe obesity, which make it difficult to measure abdominal circumference at the midpoint between the iliac crest and the last rib ${ }^{16}$.

The present study was conducted according to the guidelines laid down in the 
Declaration of Helsinki, and it was approved by the Research Ethics Committee of University Hospital, Ribeirão Preto Medical School, USP (Protocol number 2937/2007). All participants signed a written Informed Consent Form.

The data were entered into Excel spreadsheets, and statistical analysis was performed using the Statistical Package for the Social Sciences (SPSS Inc., Chicago, llinois, United States) 16.0 software. The data obtained at the beginning and at the end of the study were compared by the nonparametric Wilcoxon test, and the associations between variables were determined using the Pearson correlation coefficient. The results are expressed as median (range). Differences between variables were considered to be significant when $p<0.05$.

\section{RE S U L T S}

The results showed a significant loss of body weight $(p=0.005), \mathrm{BMI}(p=0.005)$, abdominal circumference $(p=0.005)$, fat mass $(p=0.005)$, and fat-free mass $(p=0.008)$ after seven days of calorie restriction (Table 1).

Although not significant, the REE reduction was approximately $124 \mathrm{kcal} /$ day (5\%)
(Table 1). The substrate oxidation rates were not significantly changed. A positive correlation was observed only between body weight reduction and fat-free mass reduction $(r=0.753$ and $p=0.012$ ).

\section{DISCUSSION}

The positive correlation between body weight reduction and mass reduction associated with a $5 \%$ reduction in REE suggests that morbidly obese individuals have a stronger reduction in fatfree mass than in other components of body composition, and this fact can lead to a decrease in REE. The results obtained corroborate the findings of Fullmer et al. ${ }^{19}$ that showed that caloric restriction leads to fat-free mass loss.

Fat-free mass loss may have some consequences such as cardiac failure and cancer because these diseases are often associated with rapid and extensive loss of muscle mass. Muscle plays a central role in whole-body protein metabolism by serving as the principal reservoir for amino acids to maintain protein synthesis in vital tissues and organs in the absence of amino acid absorption from the gut and by providing hepatic gluconeogenic precursors. Therefore, muscle metabolism plays a key role in the prevention of many chronic diseases ${ }^{20}$.

Table 1. Comparison of the median values of the variables obtained on day 1 and day 8 of the experiment conducted in 10 morbidly obese women (body mass index $>40 \mathrm{~kg} / \mathrm{m}^{2}$ ) subjected to short-term caloric restriction. Ribeirão Preto (SP), Brazil, 2007-2008.

\begin{tabular}{lrrrr}
\hline Variables & \multicolumn{2}{c}{ Day 1} & \multicolumn{2}{c}{ Day 8} \\
\hline Body weight $(\mathrm{kg})$ & 142.6 & $(112.0-152.2)^{*}$ & 140.0 & $(110.6-149.6)^{*}$ \\
Body mass index $\left(\mathrm{kg} / \mathrm{m}^{2}\right)$ & 49.7 & $(45.6-59.8)^{*}$ & 48.7 & $(44.8-58.8)^{*}$ \\
Abdominal circumference $(\mathrm{cm})$ & 136.1 & $(120.9-155.2)^{*}$ & 133.9 & $(120.6-154.8)^{*}$ \\
Fat mass $(\mathrm{kg})$ & 67.6 & $(51.1-77.8)^{*}$ & 65.6 & $(50.2-75.0)^{*}$ \\
Fat-free mass $(\mathrm{kg})$ & 72.3 & $(60.9-75.7)^{*}$ & 71.4 & $(60.4-75.5)^{*}$ \\
Volume of oxygen consumed (mL/min) & 322.5 & $(273.0-451.0)$ & 305.0 & $(207.0-391.0)$ \\
Volume of carbon dioxide produced (mL/min) & 257.0 & $(209.0-581.0)$ & 236.0 & $(158.0-636.0)$ \\
Respiratory quotient & 0.8 & $(0.8-1.3)$ & 0.8 & $(0.8-1.6)$ \\
Resting energy expenditure (kcal/day) & 2232.0 & $(1880.4-3484.3)$ & 2108.3 & $(1423.8-3231.2)$ \\
Lipid oxidation (g/day) & 141.4 & $(-327.0-177.9)$ & 117.7 & $(-604.8-202.4)$ \\
Glucose oxidation (g/day) & 153.2 & $(87.5-1695.9)$ & 139.6 & $(51.2-2338.5)$ \\
Protein oxidation (g/day) & 56.5 & $(38.9-88.6)$ & 58.6 & $(23.4-69.0)$ \\
\hline
\end{tabular}

Note: ${ }^{*} p<0.05$ 
The synthesis and breakdown of muscle protein are principally responsible for the energy expenditure of resting muscle. The energy expenditure related to muscle metabolism is the only component of REE that might vary considerably ${ }^{20}$.

The short-term caloric restriction, under controlled conditions for consumption and activity, enabled a clinical observation of a decrease in energy expenditure in one week only.

Bosy-Westphal et al. ${ }^{21}$, studying obese and overweight women receiving a low calorie diet for 12 weeks, also detected loss of weight, fat-free mass, and fat mass and $8 \%$ reduction in REE. In obese individuals, greater weight loss is associated with a large decrease in REE (about $140 \mathrm{kcal} /$ day $)^{22,23}$.

In contrast, Weyer et al. ${ }^{24}$ detected changes in respiratory quotient and REE even with gradual weight loss. It should be kept in mind, however, that their study was conducted over a much longer period, about four years.

A recent study comparing metabolic adaptation following massive weight loss after bariatric surgery or after calorie restriction plus vigorous exercise has associated adaptation with the degree of energy imbalance. In both groups, based on measured body composition changes, the decrease in resting metabolic rate was greater than expected. The group that showed weight loss after calorie restriction plus vigorous exercise preserved more fat-free mass than the group that showed weight loss after bariatric surgery. The magnitude of this metabolic adaptation was correlated with the degree of energy imbalance $(r=0.55, p=0.004)$, suggesting that the metabolic adaptation was related to the degree of energy imbalance ${ }^{25}$. However, according to Westerterp ${ }^{26}$, over- or underfeeding induces an increase or decrease in energy expenditure. Thus, the adaptive tendency alternating overfeeding and underfeeding with an iso-energetic amount results in positive energy balance. Therefore, it indicates the tendency to preserve energy, as shown in the present study.
The nonsignificant REE and substrate (lipid and glucose) oxidation rate reduction observed here might have been due to the short-term of caloric restriction. One possible explanation for these results is that the response time to reduce these parameters varies between morbidly obese individuals. There is an important variation in REE over a short- and long-term with respect to weight loss in obese individuals, regardless of the strategy used. It is still unclear whether this variability is related to treatment or to the patient ${ }^{21}$.

In contrast to the present study, after administering a low calorie diet to obese women for 10 weeks, Labayen et al. ${ }^{27}$ found significant glucose oxidation reduction. However, these authors did not observe changes in lipid oxidation.

Changes in REE are important for body weight changes. Factors such as age, fat mass, fat-free mass, sex, and hormones are known to be related to energy expenditure ${ }^{28}$. Weyer et al. ${ }^{24}$ observed a considerable variation in adaptation among certain individuals; such variation could not be explained by changes in fat-free mass or fat mass or by physical activity.

The body weight reduction found in the present study was positively correlated with fat-free mass reduction. This finding supports the reports of Van Gaal et al..$^{28}$ who, in a study on short- and long-term effects of very low calorie diets on REE, observed that weight and fat-free mass significantly reduced over the short-term together with to a REE reduction. However, after a long period of weight loss, these authors did not detect fat-free mass reduction. They stated that changes in fat-free mass are important for changes in REE. It is likely that morbidly obese individuals have different responses to the loss of fat-free mass over a short-term, and this may help decrease the REE.

\section{CONCLUSION}

The resting energy expenditure adaptive response of morbidly obese women subjected to 
short-term energy restriction showed 5\% reduction in REE and correlation between weight loss and fat-free mass, which indicates the influence of fat-free mass on the decrease in REE. Therefore, short-term caloric restriction in morbidly obese women led to decrease in REE and fat-free mass, which suggests a rapid adaptation of energy expenditure.

\section{ACKNOWLEDMENTS}

The authors are grateful for the financial support provided by the Fundação de Apoio ao Ensino, Pesquisa e Assistência of the University Hospital of Ribeirão Preto Medical School, Universidade de São Paulo, and for the research scholarship (MSc) granted to Andresa Toledo Triffoni-Melo by Coordenação de Aperfeiçoamento de Pessoal de Nível Superior.

\section{CONTRIBUTORS}

AT TRIFFONI-MELO and RW DIEZ-GARCIA were responsible for the design, data collection, literature review, data analysis, and writing of the manuscript. CMM RESENDE contributed to data collection, data analysis, and writing of the manuscript. VMM SUEN and CBM BRAGA contributed to data analysis and writing of the manuscript. RW DIEZ-GARCIA supervised this study. All authors were responsible for the critical review of the manuscript.

\section{REFERE N CES}

1. Fricker J, Rozen R, Melchior JC, Apfelbaum M. Energy-metabolism adaptation in obese adults on a very-low-calorie diet. Am J Clin Nutr. 1991; 53(4):826-30.

2. Das SK, Roberts SB, McCrory MA, Hsu LK, Shikora SA, Kehayias JJ, et al. Long-term changes in energy expenditure and body composition after massive weight loss induced by gastric bypass surgery. Am J Clin Nutr. 2003; 78(1):22-30.

3. Wang X, You T, Lenchik L, Nicklas BJ. Resting energy expenditure changes with weight loss: Racial differences. Obesity. 2010; 18(1):86-91. http://dx. doi.org/10.1038/oby.2009.163

4. Jonge L, Bray GA, Smith SR, Ryan DH, Souza RJ, Loria CM, et al. Effect of diet composition and weight loss on resting energy expenditure in the Pounds Lost study. Obesity. 2012; 20(12):2384-9. http://dx.doi.org/10.1038/oby.2012.127

5. Bosy-Westphal A, Schautz B, Lagerpusch M, Pourhassan M, Braun W, Goele K, et al. Effect of weight loss and regain on adipose tissue distribution, composition of lean mass and resting energy expenditure in young overweight and obese adults. Int J Obes. 2013; 37(10):1371-7. http://dx. doi.org/10.1038/ijo.2013.1

6. Iannelli A, Martini F, Rodolphe A, Schneck AS, Gual P, Tran A, et al. Body composition, anthropometrics, energy expenditure, systemic inflammation, in premenopausal women 1 year after laparoscopic Roux-en-Y gastric bypass. Surg Endosc. 2014; 28(2):500-7. http://dx.doi.org/10.1007/s00464013-3191-1

7. Hopkins M, Gibbons C, Caudwell P, Hellström PM, Näslund $E$, King NA, et al. The adaptive metabolic response to exercise-induced weight loss influences both energy expenditure and energy intake. Eur J Clin Nutr. 2014; 68(5):581-6. http://dx.doi.org/ 10.1038/ejcn.2013.277

8. Sacks FM, Bray GA, Carey VJ, Smith SR, Ryan DH, Anton SD, et al. Comparison of weight-loss diets with different compositions of fat, protein, and carbohydrates. N Engl J Med. 2009; 360(9):859-72. http://dx.doi.org/10.1056/NEJMoa0804748

9. Blair-West GW. Tantalus, restraint theory, and the low-sacrifice diet: The art of reverse abstraction $10^{\text {th }}$ International Congress on Obesity; September 4, 2006; Sydney, Australia - Symposium: Obesity management: Adding art to the science, invited presentation. Med Gen Med. 2007; 9(4):18.

10. Sturm R. Increases in morbid obesity in the USA: 2000-2005. Public Health. 2007; 121(7):492-6. http://dx.doi.org/10.1016/j.puhe.2007.01.006

11. Redman LM, Heilbronn LK, Martin CK, Jonge L, Williamson DA, Delany JP, et al. Metabolic and behavioral compensations in response to caloric restriction: Implications for the maintenance of weight loss. PLoS ONE. 2009; 4(2):e4377. http:// dx.doi.org/10.1371/journal.pone.0004377

12. Kerksick C, Thomas A, Campbell B, Taylor L, Willborn C, Marcello B, et al. Effects of a popular exercise and weight loss, body composition, energy expenditure and health in obese women. Nutr Metab. 2009; 6:23. http://dx.doi.org/10.1186/17 43-7075-6-23

13. Weir JBV. New methods for calculating metabolic rate with special reference to protein metabolism. J Physiol. 1949; 109(1-2):1-9.

14. Frayn KN. Calculation of substrate oxidation rates in vivo from gaseous exchange. J Appl Physiol. 1983; 55(2):628-34. 
15. Schutz Y. The basis of direct and indirect calorimetry and their potentials. Diabetes Metab Rev. 1995; 11(4):383-408.

16. Sievenpiper JL, Jenkins DJA, Josse RG, Leiter LA, Vuksan V. Simple skinfold-thickness measurements complement conventional anthropometric assessments in predicting glucose tolerance. Am J Clin Nutr. 2001; 73(3):567-73.

17. Triffoni-Melo AT, Santos RCL, Diez-Garcia RW. Effect of weight and body composition changes on waist measurement of severely obese women receiving carbohydrate-restricted diet. Rev Nutr. 2014; 27(1):5-13. http://dx.doi.org/10.1590/1415-5273 2014000100001

18. Dermura S, Yamaji S, Goshi F, Nagasawa Y. The influence of posture change on measurements of relative body fat in bioimpedance analysis method. J Physiol Antropol Appl Human Sci. 2011; 20(1):29-35.

19. Fullmer S, Reed BL, Eggett DL, Davidson RT, Nyland NK. The effect of calorie deficits of $25 \%, 40 \%$ and $55 \%$ on adaptation to resting energy expenditure and lean mass in healthy post-menopausal women. Obes Metab-Milan. 2009; 5(3/4):121-8.

20. Wolfe RR. The underappreciated role of muscle in health and disease. Am J Clin Nutr. 2006; 84(3):475-82.

21. Bosy-Westphal A, Kossel E, Goele K, Later W, Hitze $B$, Settler $U$, et al. Contribution of individual organ mass loss to weight loss-associated decline in resting energy expenditure. Am J Clin Nutr. 2009; 90(4):993-1001. http://dx.doi.org/10.3945/ajen.20 08.27402

22. Bray GA, Smith SR, DeJonge L, de Souza R, Rood J, Champagne CM, et al. Effect of diet composition on energy expenditure during weight loss: The Pounds Lost study. Int J Obes. 2012; 36(3):448-55. http://dx.doi.org/10.1038/ijo.2011.173
23. Bosy-Westphal A, Schautz B, Lagerpusch M, Pourhassan M, Braun W, Goele K, et al. Effect of weight loss and regain on adipose tissue distribution, composition of lean mass and resting energy expenditure in young overweight and obese adults. Int J Obes. 2013; 37(10):1371-7. http:// dx.doi.org/10.1038/ijo.2013.1

24. Weyer C, Pratley RE, Salbe AD, Bogardus C, Ravussin E, Tataranni PA. Energy expenditure, fat oxidation, and body weight regulation: A study of metabolic adaptation to long-term weight change. J Clin Endocrinol Metab. 2000; 85(3):1087-94.

25. Knuth ND, Johannsen DL, Tamboli RA, MarksShulman PA, Huizenga R, Chen KY, et al. Metabolic adaptation following massive weight loss is related to the degree of energy imbalance and changes in circulating leptin. Obesity. 2014; 22(12):2563-9. http://dx.doi.org/10.1002/oby.20900

26. Westerterp KR. Metabolic adaptations to over-and underfeeding-still a matter of debate? Eur J Clin Nutr. 2013; 67(5):443-5. http://dx.doi.org/ 10.1038/ejcn.2012.187

27. Labayen I, Díez N, Parra D, González A, Martínez JA. Total and endogenous lipid oxidation in obese women during a 10 weeks weight loss program based on a moderately high protein energyrestricted diet. Nutr Res. 2004; 24(1):7-18. http:// dx.doi.org/10.1016/j.nutres.2003.09.004

28. Van Gaal LF, Vansant GA, De Leeuw IH. Factors determining energy expenditure during very-lowcalorie diets. Am J Clin Nutr. 1992; 56(1 Suppl.):224S-9S.
Received: November 11, 2014

Final version: June 8, 2015

Approved: June 24, 2015 
